\title{
Empathy, honour, and the apprenticeship of violence: rudiments of a psychohistorical critique of the individualistic science of evil
}

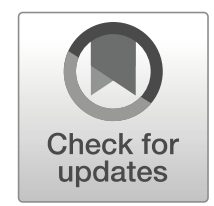

\author{
Nicolas J. Bullot ${ }^{1}$ (D) \\ Published online: 28 December 2019 \\ (C) The Author(s) 2019
}

\begin{abstract}
Research seeking to explain the perpetration of violence and atrocities by humans against other humans offers both social and individualistic explanations, which differ namely in the roles attributed to empathy. Prominent social models suggest that some manifestations of inter-human violence are caused by parochial attitudes (attitudes characterized by interests centred on one's own community) and obedience reinforced by within-group empathy. Individualistic explanations of violence, by contrast, posit that stable intra-individual characteristics of the brain and personality of some individuals lead them to commit violence and atrocities. An individualistic explanation argues that the chief cause of violence is the perpetrator"s lack of empathy with the victim. To offer the rudiments of a critique of the individualistic approach, I critically examine a model stating that violence is caused by empathy erosion (Baron-Cohen 2011). Specifically, the discussion of the empathy-erosion model is applied to the case of honour-based violence (HBV), a type of violence known for its communal character. Building from prior enquiries into violence and social cognition, I argue that an empathy-erosion explanation of $\mathrm{HBV}$ is defective because it does not consider important cultural and historical enablers of violence. Finally, as an alternative to individualism, I propose a psychohistorical approach to HBV in the migration context. This alternative combines psychological and philosophical enquiry with historical and ethnographical analysis. The psychohistorical approach hypothesises that distinct processes of cultural learning of honour codes both scaffold HBV and modulate the perpetrators' emotions and empathy.
\end{abstract}

Keywords Violence - Empathy · Honour-based violence · Identity fusion - Sacred values · Cultural learning · Atrocity · Explanation · Evil · Psychological individualism ·

Psychohistorical philosophy $\cdot$ Scaffold

Nicolas J. Bullot

nicolas.bullot@cdu.edu.au

1 ArtLab, College of Indigenous Futures, Arts \& Society, Charles Darwin University, Casuarina Campus, Orange Precinct 6.1.17, Ellengowan Drive, Brinkin, Northern Territory 0811, Australia 


\section{Social and individualistic explanations of violence}

A number of researchers have sought to offer scientific and naturalistic explanations of radical acts of violence, sometimes referred to as "evil" actions or atrocities. In their research, the term violence typically refers to aggressive actions in which an individual or collective of perpetrators regard inflicting pain, suffering, injury, maiming, or death on a victim as the necessary means to a social end (see Fiske and Rai 2015: Ch. 1). ${ }^{1}$ Naturalistic explanations of violence vary in the description of the causal weights ascribed to either individual dispositions or social factors. Social models posit that some sweeping social systems have the propensity to cause violence. For example, Stanley Milgram (1974/2004), Philip Zimbardo (2007), Kwame A. Appiah (2010), Alan P. Fiske and Tage S. Rai (2015) emphasise that social situations and obedience to moral codes can compel ordinary individuals to commit acts of violence.

According to Zimbardo (2007), the primary causes of "evil" actions are social factors that include group conformity and uncritical obedience to authority (2007: ch. 12), deindividuation that reduces perpetrator accountability (2007: p. 298-307), dehumanisation and moral disengagement (p. 307-13), and bystander apathy (p. 307-19). In another social theory, Fiske and Rai (2015) argue that violence is often morally motivated and aimed at establishing social relationships. Perpetrators typically intend to harm or kill their victims in order to constitute a social relationship that satisfies the perpetrators' prescriptive moral model of what the relationship ought to be (Fiske and Rai 2015). Other social explanations of violence refer to cultural systems that foster inter-group competition and parochialism (e.g., Choi and Bowles 2007; Ginges and Atran 2011; Staub 2003; Swann Jr. et al. 2010).

By contrast, other accounts elucidate violence by focusing on factors inherent in an individual perpetrator. Adapting terminology from philosophy of the cognitive sciences (Burge 1986; Wilson 1992), ${ }^{2}$ I propose to categorise the latter as psychologically individualistic explanations, which can be identified by two criteria. First, an explanation of violence is individualistic in that sense if it localises the primary cause of violent action inside the individual perpetrator's organism or brain. And second, it lacks a substantive analysis of the social factors that facilitate or enable violence.

Some individualistic explanations posit that violence is caused by the atypical personalities and disordered brains of certain kinds of people, including "evil" or aggressive individuals, persons with empathy disorders, and psychopaths. For a number of individualists, such atypical psychological traits are what confers on these people the propensity to act violently. For example, in the debate about gun violence (Gold and Simon 2016; McGinty et al. 2013), a contested yet common individualist explanation posits that gun violence is caused by mental illness (Metzl and MacLeish 2015). This explanation aligns with the aforementioned criteria. First, it locates the chief cause of gun violence in a disorder affecting mental mechanisms located inside the perpetrator's head. Second, the explanation does not analyse social contributors to gun violence, which could include the

\footnotetext{
1 This conceptualisation is focused on the most direct manifestations of violence; and it differs from normative approaches based on wider conceptualisations of violence and power (e.g., Galtung 1990; Lukes 2005).

2 Specifically, I refer to the distinction between "wide" methodologies for the study of the mind (Clark and Chalmers 1998; Wilson 2004) and individualistic methodologies in cognitive science (Fodor 1980; Marr 1982), which differ from a number of individualist methodologies (see, for example, the discussions of methodological individualism by Lukes 1968; Watkins 1957).
} 
degree of availability of firearms and social contagion (Metzl and MacLeish 2015; Towers et al. 2015).

Individualistic approaches to violence occur in both intuitive explanations of violence and legal frameworks that codify intuitive interpretations of violent behaviours (see, for example, Honderich 2002; Morton 2004; Zimbardo 2007: p. 7-8, 320-21). As an example of intuitive individualism, consider the opening of U.S. marksman Chris Kyle's autobiography (Kyle et al. 2012). This text includes a narration of Kyle's first act of killing in Irak; he shot a woman who was attempting to throw a grenade at a unit of U.S. Marines. Kyle reflects on this experience as follows: "It was my duty to shoot (...). My shots saved several Americans, whose lives were clearly worth more than that woman's twisted soul. (...) I truly, deeply hated the evil that woman possessed." (Kyle et al. 2012: p. 4). This account is individualistic because, first, it locates the cause of the woman's decision to undertake violent action in her mentality described as "evil". Second, he does not refer to any social factors that might explain her action.

In scientific contexts, individualistic explanations have focused on psychological mechanisms such as lack of empathy (Baron-Cohen 2011) and personality traits (Anderson and Bushman 2002). In what follows, I examine the hypothesis that a core cause of violence is the perpetrator's lack of empathy (e.g., Baron-Cohen 2011; Lakoff 2009/2008). Simon Baron-Cohen (2011) has proposed a model built on that idea, which hypothesises that violent acts are caused by the perpetrator's loss of the capacity for empathy; he terms this phenomenon empathy erosion.

In Baron-Cohen's model, empathy denotes "our ability to identify what someone else is thinking or feeling and to respond to their thoughts and feelings with an appropriate reaction" (Baron-Cohen 2011: p. 16). According to the model, all humans fit onto an empathy bell curve ranging from zero to six (zero = no empathy, six = super empathy). The Empathy Quotient (EQ) questionnaire measures two aspects of empathy: first, the recognition of another's feelings and, second, the ability to react to those feelings with a fitting response. Most people fit within the range from two to four, whereas those who show no empathy centre on zero, defined as "zero degrees" of empathy. People in this range are described as having no awareness of the perceptions of others and lacking the capacity to anticipate their feelings and reactions. There are two types of zero degrees of empathy, negative and positive. Those with "zeronegative" degrees of empathy suffer from deficits in socio-emotional tasks, and are often diagnosed with psychopathy (type P), narcissism (type N), or borderline personality disorder (type B).

Baron-Cohen (2011) describes those with type P, N, or B disorders as having a permanent loss of empathy, whereas other sub-types of zero-negative degrees of empathy exist in cases of temporary losses of empathy. Temporary losses of empathy might occur, with alcohol, fatigue or depression as well as circumstantial events such as "heat of passion" crimes or murder in self-defence. This fleeting loss of empathy explains why ordinary people can commit acts of evil and is described as underactivity in the neural empathy circuit occurring at the time of performing the act.

Baron-Cohen's explanation is individualistic because it locates the primary cause of violence against others in the dispositions of the individual perpetrator, and specifically in the empathy-impaired brain of that individual. Moreover, his explanation does not significantly integrate factors identified by social theories; for example, it does not examine whether empathy is modulated by social factors like parochialism and cultural 
context. In what follows, I engage with two questions raised by the rift between social explanations and Baron-Cohen's individualistic model. First, what are the challenges faced by individualistic explanations of violence, and most specifically by BaronCohen's (2011) theory of empathy erosion? Second, is there an approach to the explanation of violence that can combine insights provided by both individualistic and social accounts of violence? To address the first question, in Section 2, I apply Baron-Cohen's hypotheses to the specific topic of honour-based violence (henceforth "HBV"). Then, in Section 3, I argue that the resulting individualistic model of HBV based is defective because it does not account for important triggers of HBV. In Section 4, I propose an alternative to individualistic explanations that addresses the second question. It consists in integrating evidence offered by research about the mental mechanisms of violent behaviour with ethnographic and historiographical research about violence.

\section{Applying the empathy-erosion model to honour-based violence}

In his model, the prediction made by Baron-Cohen (2011) that perpetrators of violence suffer from empathy erosion holds regardless of the type of violence perpetrated. For example, the hypothesis suggests that killings in the context of organised crime, honour conflicts, and genocides are all caused by empathy erosion. This prediction, so I argue, encounters difficulties when applied to violence motivated by stern or patriarchal codes of honour, which is known as honour-based violence ("HBV"; see, for example, Belfrage et al. 2012; Gill et al. 2014) and honour crimes (Elakkary et al. 2014; Sen 2005).

HBV is motivated by matters of honour; but the customs of honour adopted by human communities are diverse (Gill 2014b; Oprisko 2012; Strange 2014). To conceptualise honour in its diversity, Appiah (2010: Ch. 5) argues that having honour refers to the idea of being entitled to respect on the basis of norms that vary across cultural contexts. Some communities exhibiting a concern with honour have an honour code, which is a set of shared norms regarding how the right to respect should be bestowed. An honour code specifies how certain kinds of people can obtain the right to respect, how they can lose it, and what actions should be undertaken in case of significant change in honourability (Appiah 2010: p. 175).

Cross-cultural ethnographical, historical, and semantic enquiries have demonstrated that honour codes vary across historical contexts (Appiah 2010; Gill 2014b). This diversity can be illustrated by a rule upheld by some patriarchal codes of honour, which states that a father has a duty to "protect" his daughter's virginity and chastity (prior to her marriage) with the help of his family; and that he and his family should lose their right to respect (their honour) if they fail to comply with that duty. Far from being universal, that norm about virginity is rejected by a wide range of communities organised by different customs in the management of the right to respect (Okin 1999; Wikan 2008: Ch. 5-6).

Patriarchal norms aimed at protecting female virginity and chastity play a role in HBV. This can be illustrated by so-called "honour killings" in the migration context, which is analysed in Section 4. This type of HBV follows a script in which a woman living in a nation-state is murdered by a male relative who - like her - pertains to a 
cultural minority in the country where they migrated. The murder appears to be committed in retaliation for her disobedience in a matter regarding her sexuality. The case of Fadime Sahindal follows this script (Akpinar 2003; Kurkiala 2003; Wikan 2008).

Fadime Sahindal (1975-2002) moved to Sweden with her family when she was seven years old. Fadime was of Kurdish descent and was raised in the Western nation-state of Sweden. While undertaking a university degree, she met a Swedish man with whom she fell in love. Fadime was aware that having sexual relations with a person neither chosen nor approved by her father was considered an act potentially worthy of death in communities where honour codes are tied to strict control of women's sexuality (Appiah 2010; Coomaraswamy 2005). Her family upheld such a strict honour code (Kurkiala 2003; Wikan 2008: p. 1). Upon hearing of her relationship with the Swedish man in 1998, Fadime's family was distraught (2008: p. 110-11) and her father and brother attacked and threatened her (2008: p. 15). The attack led Fadime to approach the Swedish police (2008: p. 15) and the media (2008: p. 110), leading to a trial and a conviction of Fadime's brother (2008: p. 111). Subsequently, she avoided her family home for fear of another violent reprisal. Fadime chose to make her case public and told her story to the Swedish Parliament; her hope was that her case could pave the way for increased understanding of violence against immigrant women in Swedish society. In 2002, she decided to secretly visit her sister's apartment; but her father, Rahmi Sahindal found out about the visit and fatally shot her in front of her mother and sisters (21 January 2002). The murder of Fadime Sahindal in Sweden caught the attention of a number of European governments, non-governmental organisations, and human-rights activists (Husseini 2011).

Other cases of honour-based crimes in the migration context follow a similar script (Idriss 2011; Sen 2005). In these cases, the violent form of control deployed by the father and his associates raises complex questions about the relations between empathy toward a family member and the decision to act violently. It is possible that, in the past of their relationship, the perpetrators of an honour killing had interacted with their victim with benevolent and empathic feelings. But at the occasion of the killing or its justification, the perpetrators identify the victim as someone worthy of mortal punishment. Thus, some important factors have led perpetrators to desire the victim's death. Now consider how Baron-Cohen's individualistic model could be deployed to help identify these factors.

Baron-Cohen's model suggests an explanation based on a cluster of five hypotheses, which follow the individualistic heuristics proposed by Baron-Cohen. The most central may be expressed as follows:

Empathy Erosion. Acts of radical cruelty or violence perpetrated in 'honour' killings and other forms of HBV are evidence of a lack of empathy of the perpetrator(s) for the victim.

In the case of Fadime Sahindal, this predicts that Fadime's father was lacking empathy for her when he decided and performed her killing.

If one follows the logic of Baron-Cohen's model, it predicts that the lack of empathy of Fadime's father, Rahmi Sahindal, could have fallen under the two categories of empathy erosion posited by Baron-Cohen. This leads to this hypothesis:

Violence Enabled by Low EQ. Perpetrators of HBV suffer either from a long-lasting and entrenched low empathy quotient (EQ) or from a temporary lapse of empathy during the planning and execution of the act of violence. 
Similarly, Baron-Cohen's model offers a prediction about the personality types of long-term sufferers of a lack of empathy:

Low-EQ Personalities. Those with a long-lasting and deeply entrenched lack of empathy who perform acts of HBV typically belong to one of these three categories: types $\mathrm{P}, \mathrm{N}$ and $\mathrm{B}$ (see above).

In the case of Fadime Sahindal's murder, the individualistic interpretation therefore suggests that her father's empathy erosion, which led him to enact his decision to kill her, might have been a temporary loss or a long-lasting lack of empathy. If he suffered from longlasting lack of empathy, his brain mechanisms would have been impaired in the manner predicted by a specific category of empathy erosion (type $\mathrm{P}, \mathrm{N}$, or B).

Baron-Cohen argues that empathy erosion typically comes with an impairment in the capacity to develop an understanding of others' minds, which he calls mindreading (Baron-Cohen 2011: p. 42-43). Consequently, his approach suggests this additional prediction:

Mindreading Impairment. A violent perpetrator's abilities to keep track of a victim with accuracy in mindreading (thus, to track the victim as an agent) are typically impaired - in other terms, this corresponds to an impairment in interpersonal sensitivity (Hall and Bernieri 2001), and the psychological tracking of a person (Bullot 2014, 2015).

The idea associated with Mindreading Impairment can also be interpreted in terms of objectification, as follows:

Person Objectification. In the execution of HBV, a perpetrator keeps track and responds to the victim as if the victim was an object without sentience, rather than $a$ sentient agent with mental states.

\section{Objections presented to the individualistic approach of the empathy-erosion model}

The individualistic explanation of HBV based on the preceding hypotheses faces serious challenges; there are at least five objections to an empathy-erosion model applied to HBV, which collectively suggest that the individualistic approach of the model overlooks significant contextual factors.

\subsection{Objection from causal misattribution by neglect of social factors}

According to a first objection, explanatory models of violence focused on personality and individual dispositions alone commit an erroneous causal attribution. ${ }^{3}$ This is because these explanations fail to take into consideration a cluster of social factors described in social psychology as the "full force" of social situations (Zimbardo 2007: p. 210-212). In the case of HBV, social situations inherit their force from honour codes and social factors that propel the perpetrator's violence and his eagerness to demean the victim (see Section 3). The social factors driving violence that are screened out by individualistic explanations include the obedience of perpetrators to cultural authorities and moral codes that recommend aggression against outgroup members and dissenting ingroup members (Zimbardo 2007: ch. 12),

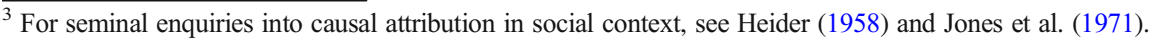


deindividuation processes that reduce the perpetrator's personal accountability (Zimbardo 2007: p. 298-307), feelings of humiliation and lack of social recognition among the perpetrators' cultural group (Moisi 2010; O’Neill and Smith 2012; Taylor 1994), and a diversity of other historically contingent economic and legal circumstances. Other important social factors include the dehumanisation of victims (D. L. Smith 2011; Zimbardo 2007: p. 307-13) and bystander apathy (Zimbardo 2007: p. 313-19). Hence, according to the objection, a typically individualistic explanation of violence is incomplete because it does not acknowledge the causal roles played by any of the aforementioned social factors.

The significance of social factors in the case of Fadime Sahindal's murder (Wikan 2008) aptly illustrates the point made by the objection. An advocate of the individualistic approach may argue that Fadime's killing is explained by the fact that her murderer (her father) had a low-EQ personality. But this explanation would be incomplete even if the Low-EQ Personality hypothesis was true in this case (which is unlikely; see Wikan's 2008 analysis ${ }^{4}$ of his trial). This is because this kind of individualistic explanation does not examine the social process that lead to the cultural transmission of patriarchal honour codes and motivate cooperation among perpetrators (see Sections 3.3 and 4).

To Scott Atran $(2003,2014)$, this objection is particularly relevant to critically evaluate individualistic explanations of suicide terrorism. In response to Lankford's (2014) view that suicide terrorists suffer from personality disorders and show suicidal tendencies, Atran (2014) states that Lankford's claims "manifest a form of fundamental attribution error", which he characterises as a tendency "to overestimate effects of personality and underestimate situational effects in explaining social behaviour" (2014: p. 362). By contrast to individualistic explanations, Atran and his colleagues argue that typical suicide terrorists lack diagnosable psychological anomalies and are incentivised to commit acts of violence (Atran 2003; Atran et al. 2014). This incentivisation relies on socially-transmitted sacred values and "identity fusion". The mechanisms of identity fusion are systems that cause susceptible agents to align their personal and group identities. This fusion, in turn, leads them to consent to radical selfsacrifices and violence in the service of other members of their ingroup (Swann Jr. et al. 2014; Swann Jr. et al. 2009). As argued in Sections 3.3 and 4, the factor of identity is relevant to analysing HBV. The decision by Fadime's father to kill her was incentivised by ingroup peers of his Kurdish familial community, and his obedience to their code of honour may be indicative of his propensity to fuse his personal identity with the identity of his cultural group.

\subsection{Objection from the ordinariness of perpetrators}

The anti-individualistic position defended by Atran (2014) is reminiscent of a hypothesis introduced in the research on genocides, which is consistent with the preceding objection. This is the hypothesis of the ordinariness of perpetrators (sometimes misnamed as "banality of evil" hypothesis), which emerged from debates on the

\footnotetext{
${ }^{4}$ According to Wikan's (2008: p. 106) account, the psychiatric report on the perpetrator of Fadime's killing indicated that he was not suffering from a diagnosable mental disorder, although he was described as lacking the ability to empathise (p. 106).
} 
writings of Hannah Arendt (1963) and Stanley Milgram (1974/2004). It posits that most perpetrators of genocides are seemingly ordinary people, merely complying with orders and routines of obedience. The hypothesis has been adopted as a working hypothesis and refined by research on the situational factors that enable genocides (Browning 1992/2001; Hinton 2004; Waller 2002), suicide terrorism (Atran 2014), and violence in general (Zimbardo 2007). The hypothesis implies that violence-eliciting norms and specific historical contexts can compel a wide range of ordinary individuals with diverse personality types to contribute to acts of genocidal violence. The hypothesis of ordinariness of perpetrators counters the individualistic psychology of violence because it primarily identifies the factors that explain radical violence (the explanans of violence) with broader systems of social control (as opposed to dispositions located into a single individual).

When applied to HBV, the hypothesis of the ordinariness of perpetrators propounds that perpetrators of HBV may be obeying instructions or norms transmitted socially in their group rather than suffering from personality disorders. Thus, it directly challenges the hypothesis of Low-EQ Personalities. Perpetrators of HBV may adopt moral norms and honour codes in which HBV is reinforced by their empathy with loyal members of their ingroup (see Section 4.2).

Although Baron-Cohen (2011: p. 163-170) acknowledges that the banality of evil hypothesis challenges his model of empathy erosion, his response consists in acknowledging the modesty of his proposal and the need of an integrative model capable of describing both social-level and individual-level mental mechanisms causing violent behaviour. For example, he writes that "the argument in this book is in fact a modest proposal: namely, that both biology and environment are important" (Baron-Cohen 2011: p. 151). However, Baron-Cohen does not offer such an integrative model. Nor does he significantly amend the individualism of the core hypothesis of his empathy-erosion model, which may undercut the project of developing a genuinely integrative model.

With reference to the banality of evil, Baron-Cohen sees the role of his model as emphasising individual factors. For example, he writes: "Eichmann's behaviour needs explaining not just in terms of social forces (important as these are) but also in terms of individual factors (his reduced empathy)" (Baron-Cohen 2011: p. 166). But the problem of this response is that Eichmann may not have been lacking of empathy, but rather that he exclusive directed his empathic at his ingroup as a result of identity fusion (Bloom 2016; Swann Jr. et al. 2009). Baron-Cohen's model emphasises individual factors without integrating such factors with social factors and models (e.g., Fiske and Rai 2015; Staub 2000, 2003; Zimbardo 2007). Thus, it fails to account for situations in which empathy with ingroup members motivates perpetrators to commit violence against outgroup members or ingroup defectors (Bloom 2016, 2017a).

\subsection{Objection from parochial compliance and complicit cooperation}

Another concern with the individualistic perspective of the empathy-erosion model is that it screens out the mechanisms of cooperation implicated in the perpetration of violence. For example, the model cannot account for the fact that, in a number of welldocumented cases of $\mathrm{HBV}$, multiple individuals cooperatively plan and carry out violent acts of social control of their victim (e.g., Appiah 2010; Belfrage et al. 2012; Payton 2011; Sen 2005; Welchman and Hossain 2005). That is, a number of 
perpetrators perform joint actions, and such actions in turn express their agency as a group agent (List and Pettit 2011; Tollefsen 2015). For example, perpetrators collectively intend to control, keep track of, retaliate, and coordinate attacks against the victim. In performing these joint actions, perpetrators produce an effect - the act of violence - together. They own that violence effect in common as something they combine to intend and perform. Thus, they are responsible together for the violent act, and therefore share the responsibility of its production.

With respect to the killing of Fadime, Wikan (2008: p. 15, 114-15) reports that Fadime's father was part of a group of friends and relatives that endorsed Fadime's killing and the code of honour that prescribed it. There are other well-documented cases in which the decision to undertake an honour killing was decided at a family council meeting consisting of relatives of the victim (see Section 4). Decisions in relation to which family member(s) should perpetrate the retribution as well as the punishment type were decided at such meeting.

Acts of cooperation are recorded in other forms of collective violence, and most pervasively in the research on mass killings and genocides (Dwyer and Ryan 2012; Hinton 2004; Ryan 2010; D. N. Smith 1998; Staub 2000). As noted by Bloom (2016: p. 186-211), perpetrators of these forms of violence typically are motivated by their empathy with members of their ingroup, and may seek disproportional retaliation against outgroup member perceived as having caused harm to their ingroup. If correct, Bloom's analysis suggests that empathy works with other systems of social cooperation that can motivate parochialism and bigotry. The empathy-erosion model does not explain such acts of cooperation.

This point about cooperation also raises a concern regarding the hypothesis of violence enabled by transitory low EQ (the second part of the hypothesis of Violence Enabled by Low EQ). If perpetrators spend from weeks to months stalking the victim and deliberating their attack, this process is hardly indicative of a fleeting loss of empathy. The long-term tracking and planning rather suggests an extended reduction of empathy. Additionally, because several perpetrators might have different personality profiles, it also seems unlikely that all perpetrating relatives fit neatly into the personality trait types enumerated by Baron-Cohen (2011). Conformity among perpetrators' actions and feelings might be determined by other factors, such as shared cultural and sacred values of the ingroup instead of shared personality profile (see Section 4).

\subsection{Objection from sensitivity to conflicting norms}

A fourth objection, from sensitivity to conflicting norms can challenge the hypotheses that perpetrators are impaired in their ability to understand the mental states of the victim - see Mindreading Impairment and Person Objectification in Section 2. Similar in that respect to other types of perpetrators (Bloom 2016: p. 202-06; Bloom 2017b), some perpetrators of HBV keep track of the actions and moral choices of their victim unremittingly. This is evidenced by a type of criminal defence commonly used by perpetrators in courts, which alleges that their victims provoked them by enacting values and choices that brought 'dishonour' and shame to their community (see 'provocation defence' in Carline 2011; Idriss 2011; Warraich 2005). It is likely that such perpetrators were motivated to act violently by an acute understanding of their victim's mental states, and in particular the victim's decision to defy the perpetrators' 
moral and honour codes. This point poses a problem for Person Objectification because this hypothesis predicts that violent perpetrators in action typically keep track of their victim as an object deprived of agency and mental states.

In addition, contra Mindreading Impairment, we have no reason to exclude the possibility that HBV can depend on reciprocated mindreading by means of second and third-order thoughts. For example, a victim V's fear might be triggered by the thought that perpetrator P's correctly represent V's lasting intent to disobey P's moral code. Reciprocally, a perpetrator P's shame and anger may be reinforced by P's obsessive thoughts about V's persistent intention to defy P's moral code. P's anger might even be strengthened by P's awareness of V's understanding of P's comprehension of her intention to defy P's moral code.

These points illustrate that an explanation of HBV should account for the way perpetrators and victims reciprocally comprehend their morals, normative commitments and conflicts. Thus, sensitivity to culturally transmitted norms and moral commitments is another type of contextual sensitivity omitted by the empathyerosion model. As noted in Section 4, this reciprocal comprehension is likely to develop in a context of contrasted experiences of enculturation and moral learning (Cushman et al. 2017; Heyes and Frith 2014; Menary 2013). Enculturation is the dynamic capacity of individuals (i) to internalise community-generated experience, norms, and tools, and then (ii) to share and defend community-specific thoughts, moral values, and innovations (Downey and Lende 2012; Henrich 2016). Powered by the remarkable neural plasticity of the human brain, enculturation is a key factor that differentiates Homo sapiens from other species and accounts for diverging cultural and moral norms among human individuals and groups (Lende and Downey 2012; Tomasello 1999).

\subsection{Objection from inconclusive evidence about mental impairments}

To the best of my knowledge, cross-cultural empirical research is too scarce to directly assess the EQ and personality types of perpetrators of HBV. Thus, it is difficult to assess the hypotheses of Empathy Erosion, Violence Enabled by Low EQ, and Low-EQ Personalities in the specific contexts in which HBV occur. I was unable to find direct empirical evidence to ascertain whether or not the brain mechanisms and behaviours of perpetrators of honour killings satisfy the predictions made by Violence Enabled by Low EQ and Low-EQ Personalities. Without this evidence, it is not possible to reliably infer whether or not perpetrators of HBV fall within the "negative zero degrees of empathy" range, either consistently or intermittently.

These issues being noted, remarks made in the literature are in tension with LowEQ Personalities. First, several researchers insist that perpetrators of honour killings are not sufferers of mental disorders (Belfrage et al. 2012; Wikan 2008). For example, Belfrage et al. (2012) note that "when dealing with honour-based criminality, the planning and execution often involves multiple family members, usually without personality disorders or major mental disorders" (2012: p. 22). In the case of Fadime Sahindal for example, Wikan (2008: p. 119) reports that the psychiatric expert who examined Rahmi Sahindal for the criminal trial that convicted him of murder of his daughter (Fadime) did not agree with Mr. Sahindal's allegation that he was suffering from mental illness. 
Second, another potential insight comes from theories of violent behaviours based on identity fusion theory (Swann Jr. et al. 2009). These accounts suggest that the mechanism of identity fusion is triggered by visceral feelings of oneness with small family-like groups (Swann Jr. et al. 2014). According to Swann and colleagues (Swann Jr. et al. 2009), there is robust evidence that perpetrators willing to commit acts of extreme violence against ingroup or family members (viewed as traitors to the sacred values of the perpetrators' ingroup) are more likely to have fused identities rather than non-fused identities. This is in tension with Low-EQ Personalities because there is no evidence that identity fusion is caused by a single stable personality trait or mental disorder. Moreover, challenging Empathy Erosion, identity fusion theory contravenes the idea that the perpetrators' psychological dispositions for empathy are eroded because perpetrators with fused identity are likely to exhibit a high degree of empathy for ingroup members. Bloom $(2016,2017$ a) provides a critical assessment of empathy that is consistent with this line of argument.

\section{The psychohistorical approach to violence as an alternative to psychological individualism}

The preceding objections have identified several problems posed by Baron-Cohen's (2011) explanation of violence and by psychological individualism in general. In this section, I sketch a defence of a philosophical alternative to individualistic approach to violence and HBV. The proposed alternative consists in integrating the psychology of social cognition with research on the historical factors that can enable HBV. This line of enquiry may be termed a psychohistorical approach ${ }^{5}$ to violent behaviour. Here, I use psychohistorical to denote an explanation that integrates contributions from both (i) the psychological study of mental mechanisms and selves (Bechtel 2008; Gallagher 2011a) and (ii) the description of components of historical contexts that can influence the functioning of such mental mechanisms (Bullot and Reber 2013; Kuhn 1962/1996; Vygotsky 1987). There are at least three advantages that make the psychohistorical approach preferable to a stern version of psychological individualism.

\subsection{Conflict of identities}

First reason, a psychohistorical approach is more suitable than an individualistic model to describe how the mental processes of either perpetrators of $\mathrm{HBV}$ or victims interact with distinctive historical factors and processes of cultural transmission. In the case of HBV, a psychohistorical description of such interactions can account for important aspects of the conflict between perpetrators and victims of HBV. Figure 1 illustrates one

\footnotetext{
5 This approach is linked to earlier works adopting a psychohistorical or psychocultural approach (Arendt 1963; Bullot and Reber 2013; Gergen 1973; Lifton 1986; D. N. Smith 1998; Vygotsky 1987). However, the present account differs from psychohistorical works that were based on the principles of psychoanalytic theory alone because such works ignored contributions made by philosophers of science and cognitive scientists (see, for example, Lifton and Olson 1974). By contrast, the psychohistorical account I propose integrates philosophical research (Appiah 2010; Caporael et al. 2014; Gallagher 2011b; Gallagher and Hutto 2008; Mitchell 2009; Thagard 2019) with recent contributions to both the cognitive sciences and the social sciences (Atran 2003; Bloom 2016; Fiske and Rai 2015; Idriss and Abbas 2011; Zimbardo 2007).
} 
way in which such a description could be attempted. The schematic makes explicit a number of elements of the script of HBV introduced in Section 2. It is a simplification that can be used to reflect on the different causal systems implicated in HBV. The script describes a conflict that took place in a family of migrants pertaining to a cultural minority, ${ }^{6}$ but it is important to avoid cultural stereotypes that associate HBV to a single cultural group - see, for example, the critique of islamophobia by Gill (2014b) and Strange (2014).

Communities in which HBV occurs have been found in a diverse range of regions, which includes Europe and the Mediterranean Basin (Appiah 2010; BettigaBoukerbout 2005; Strange 2014), Western Asia and the Middle-East (Arnold 2001; Hoyek et al. 2005; Idriss 2011; Nesheiwat 2004; Warrick 2005), South Asia (Chakravarti 2005; Siddiqi 2005; Warraich 2005), and Latin America (Pimentel et al. 2005). A hypothesis adopted by several studies ${ }^{7}$ on $\mathrm{HBV}$ is that honour codes and family violence in patriarchal communities prone to HBV are aimed at controlling the sexuality of girls and women. This control of sexuality serves in turn to maintain structures of patriarchal power. Female family members are responsible for upholding familial honour through abidance by norms mandating virginity and chastity prior to marriage (Wikan 2008: Ch. 6) and fidelity afterwards (Gill 2014b: p. 4-6). Migrants from honour cultures sometimes participate in conflicts unfolding as depicted in the script $^{8}$ schematised in Fig. 1. In this script, a girl or woman rebels against patriarchal control and the honour code espoused by her family; subsequently, some family members perpetrate HBV against her in retaliation for her challenge to the honour code. Although the script leaves out the subtle complexity of each case (Gill 2014a), components of this script are present in numerous cases of HBV, including in the murders of Fadime Sahindal (see above), Shafilea Ahmed (Gill 2014a), Nadia (Wikan 2008: Ch. 14), and Banaz Mahmoud (Gill 2009; Payton 2011).

The schematic of Fig. 1 illustrates interactions between (i) the victim's decision making and the social factors that contribute to enabling the victim's attitudes of fearful defiance and (ii) the controlling decision making of a perpetrator of HBV and its historical context. Pursuing the line of enquiry developed by social models of violence, the structure of the schematic emphasises the role of antagonistic institutions and processes of cultural learning in the genealogy of the honour-based conflict. The schematic in Fig. 1 is psychohistorical because it attempts to represent dependence relations connecting the perpetrator and the victim's mental processes and historicallylocated factors that can enable HBV.

\subsubsection{Identity fusion and the perpetrators' sensitivity to violations of their honour code}

An overarching antagonism in the schematic of Fig. 1 contrasts the victim's rebellious and disobedient self to the perpetrator's aggressive self. This contrast that may be traced

\footnotetext{
${ }^{6}$ For examples of recent studies on this kind of HBV, see Baker et al. (1999), Okin (1999), Akpinar (2003), Siddiqui (2005), Wikan (2008), Abbas (2011), Payton (2011), Thapar-Björkert (2011), Belfrage et al. (2012), Gill et al. (2014).

${ }^{7}$ See, for example, Baker et al. (1999), Akpinar (2003), Sen (2005), Wikan (2008), Idriss (2011: p. 2), and Gill et al. (2014).

${ }^{8}$ Sen (2005) and Idriss (2011: p. 2) have proposed accounts that emphasise of the scripted aspects of so-called "honour killings", noting that such crimes seem to follow similar patterns.
} 


\begin{tabular}{|c|c|c|}
\hline Rebellious victim & \multirow[b]{2}{*}{$\begin{array}{c}\text { Perpetrator's } \\
\text { action }\end{array}$} & Fused perpetrator \\
\hline $\begin{array}{l}\text { Decision making } \\
\text { - Critical thinking leading to } \\
\text { distancing from values of } \\
\text { familial ingroup }\end{array}$ & & $\begin{array}{l}\text { Decision making } \\
\text { - Erosion of empathy for victim } \\
\text { - Identification with group and } \\
\text { empathy for ingroup members }\end{array}$ \\
\hline $\begin{array}{l}\text { Historical emotions of } \\
\text { unfused critical identity } \\
\text { - Desire for both familial and } \\
\text { social recognition; positive } \\
\text { appraisal of autonomy } \\
\text { - Resentment against } \\
\text { patriarchal control } \\
\text { - Fear of retaliation leading to } \\
\text { feelings of indignation }\end{array}$ & $\begin{array}{l}\text { BASED } \\
\text { VIOLENCE } \\
\text { - Antagonistic } \\
\text { cultural histories } \\
\text { - Conflict of moral } \\
\text { and honour codes } \\
\text { - Social control or } \\
\text { murder }\end{array}$ & $\begin{array}{l}\text { Emotions caused by fused } \\
\text { identity } \\
\text { - Desire for honour and } \\
\text { community recognition } \\
\text { - Feelings of shame, } \\
\text { humiliation, anger at } \\
\text { dissenting victim and critics, } \\
\text { urge to dehumanize victim }\end{array}$ \\
\hline $\begin{array}{l}\text { Multicultural development } \\
\text { - Learning of critical thinking } \\
\text { and cultural learning of a } \\
\text { democratic culture of equity }\end{array}$ & $\begin{array}{l}\text { Victim's } \\
\text { action }\end{array}$ & $\begin{array}{l}\text { Fused development } \\
\text { - Fused cultural learning, } \\
\text { including of a minority culture }\end{array}$ \\
\hline $\begin{array}{l}\text { Historical scaffolds for rebellious } \\
\text { identities } \\
\text { - Political institutions of a Western liberal } \\
\text { democracy based on the protection of } \\
\text { human rights and dignity } \\
\text { - Liberal mass media supporting } \\
\text { Western liberalism } \\
\text { - Educational institutions fostering } \\
\text { critical thinking and unfused identities }\end{array}$ & & $\begin{array}{l}\text { Historical scaffolds for identity } \\
\text { fusion } \\
\text { - Institutions of the perpetrator's } \\
\text { cultural group (e.g., educational } \\
\text { institutions fostering patriarchal values } \\
\text { and parochialism) } \\
\text { - Ingroup peer pressure and } \\
\text { cooperation } \\
\text { - Honour-based moral and retaliation } \\
\text { norms }\end{array}$ \\
\hline
\end{tabular}

Fig. 1 Psychohistorical script of an act of honour-based violence (HBV) in a migration context. The lefthand panel denotes the decision making of a victim of HBV and her historical context. The right-hand panel denotes the decision making and context of the perpetrator. Cultural learning during development entrenches both the perpetrator's fused identity and the victim's unfused critical identity. Fused identity and feelings and shame cause the perpetrator's decision to perform violent acts in retaliation for the victim's rebellion against the community's honour code. Specific historic scaffoldings support both the victim's dissent and the perpetrator's decision making. See text for further clarifications

back to different histories of cultural learning in different institutions (Section 4.2). In a context where the typical perpetrator is a migrant patriarch, plausible triggers of conflicts include the fusion of the perpetrator's with identity and honour code of his own community (ingroup), the challenges posed by the status of his ingroup as a cultural minority in a democratic state involved in nation-building (Kymlicka 2001), and the perpetrator's frustrated desire of social recognition for his ingroup's code of honour (Abbas 2011).

As noted in Sections 3.4 and 3.5, violent acts decided by perpetrators can be triggered in retaliation for the victims' violations of an honour code (Idriss and Abbas 2011; Welchman and Hossain 2005). According to the conceptual framework of identity fusion theory (Swann et al., 2009), this antagonistic response should be linked with the fusion of the perpetrators' psychological identities with the communal feelings and moral codes of their ingroup. In addition, as proposed by recognition theory (Honneth 1996; O'Neill and Smith 2012), this antagonistic response may also reflect the perpetrators' desire that their group's culture and norms be socially recognised. 
Whereas stern individualistic models disregard such pivotal social factors, psychohistorical methods are most suited to describe identity fusion and historically anchored desires for social recognition. Thus, a psychohistorical approach is needed and suitable for articulating and evaluating the hypothesis that follows, which identifies psychological processes elicited by historical conflict:

Perceived Violation of Fused Identities. To justify violent control over their victims, perpetrators of HBV lay the blame on the victims' violation of morals and honour codes held by their community. In doing so, perpetrators express personal identities and emotions fused with the values of their ingroup.

\subsubsection{The critical identities expressed by victims}

The perpetrator's self and decisions stand in vivid contrast to the female victim's rebellious self. In a number of cases, the victim's self and rebellious attitudes communicate a critical stance directed at the perpetrator's moral code and his controlling actions. Sometimes, the victims' critical attitudes voice support for democratic institutions established to uphold respect human rights and dignity (Akpinar 2003; Appiah 2010; Wikan 2008). This contrast in terms of social identities may be reinforced by a specific contrast with respect to emotions. Specifically, there are reasons to contrast the victim's fear and indignation in defending her rights to autonomy and gender equality as an individual with the perpetrator's experience of communal emotions and family shaming (Section 4.3).

These contrasts can be illustrated by the case of Fadime Sahindal, one of a series of cases in which the victims' critical identities were bond to networks of advocacy for human rights (Appiah 2010; Coomaraswamy 2005; Husseini 2011; Welchman and Hossain 2005; Wold 2019). Fadime chose to seek help from, and defend liberal democratic institutions aimed at protecting rights such as equality of men and women in front of the law, the right to freely choose a partner for developing a heterosexual relationship, and the right of women to education (Wikan 2008: p. 5). Fadime's reliance on liberal values and institutions is exemplified by decision making leading her to disobey her father's orders to end her relationship with her beloved, report to the police threats and attacks made by relatives against her, study for a university degree (2008: p. 112), appear in the media and in front of the Swedish Parliament to publicise her case (Akpinar 2003; Wikan 2008: p. 113), and violate her family's ultimatum to choose between exile or death. These actions conflicted with the sacred and patriarchal values supported by prominent members of her family. According to Wikan's (2008) analysis of her case, she "was breaking every rule in the game" of the Kurdish customs and honour code followed by her family (2008: p. 5).

\subsection{The historical scaffoldings of HBV}

A second advantage of a psychohistorical explanation compared to an individualistic approach is that the former can directly acknowledge historical factors and institutions screened out by an individualistic method. For example, it can acknowledge the role of cultural learning and the support provided by educators and institutions (Estany and Martínez 2014; Rogoff 2003; Vygotsky 1987). Adopting such a psychohistorical standpoint helps in acknowledging that institutions of cultural learning are instrumental 
to generating antagonistic feelings and desires leading to inter-human conflict and violence. This accounts for "the force of situations" in the generation of violence (Zimbardo 2007).

\subsubsection{Scaffolded triggers and antagonisms}

The two blocks at the bottom of the diagram in Fig. 1 denote learning systems described by a number of historical narratives and theories of honour-based conflicts in the migration context. These institutions are usefully described as a set of "social scaffoldings" for attitudes and antagonisms that cause HBV. In this context, the term scaffolding refers to a social system such as a school or communication tool that supports the development of a cultural behaviour over a specific period of human history.

The idea of "social scaffolding" originates in Vygotsky's (1987) work. Vygotsky offered a seminal account of the help and support that adults provide children in order for them to learn and develop complex cognitive skills. Vygotsky's conception of social scaffolding is described in his analysis of the zone of proximal development, a concept that refers to the separation between what a child can achieve alone and what that child can achieve with social help, either from adults or through collaboration with other children. This conception supports a psychohistorical and psychocultural views of development that departs from psychological individualism. In Vygotsky's tradition, Wood et al. (1976) introduced the term "scaffolding" to describe the tutoring interaction between an adult and a child; and the concept of scaffolding has been deployed by other thinkers ${ }^{9}$ to account for a variety of processes of cultural learning.

To illustrate how to investigate the scaffoldings of HBV, one could formulate the hypothesis of the scaffolded triggers of moral antagonisms, or Scaffolded Triggers for short. It can be stated thus:

Scaffolded Triggers. Through cultural learning, the perpetrators and the victims of HBV learn antagonistic norms of moral decision making, are led to make antagonistic claims to social recognition, and come to experience antagonistic emotions. Entrenched by historical and social scaffoldings, such mutually reinforcing antagonisms foster violent acts and HBV.

Recent research on HBV implies that different sorts of cultural learning are implicated in the transmission and enforcement of honour codes. This evidence suggests that some triggers of HBV are culturally transmitted by means of teaching; and that a code of honour can be taught either through childrearing and informal counselling or via formal instruction.

\subsubsection{Parenting, counselling and imitating perpetrators}

In the first place, information about an honour code can be passed from parents to child. Some aspects of that parental teaching in migrant communities is revealed by legal and research documents carried out after family crises; detailed information is available in the cases of Fadime (Wikan 2008), Banaz (Payton 2011), and Ayla (Akpinar 2003),

\footnotetext{
${ }^{9}$ See Clark (2003), Sterelny (2010), Sutton (2010), Wimsatt (2014), and Ramstead et al. (2016), among others.
} 
among others. In addition, research by some reporters and human rights activists provides anecdotical but suggestive portrayals of parental teaching in the scaffolding of HBV. For example, Wold (2019) examines in a first-person investigation a case of intergenerational $\mathrm{HBV}$; in her book, she narrates the conception of honour-based parenting held by a Jordanian man who was compelled to kill his mother as boy and decided to kill one of his daughters as an adult, in two separate acts of HBV.

It is difficult to find direct evidence that imitative and copying behaviours are instrumental in the transmission of honour codes and in the triggering of HBV. However, psychological models as different as those proposed by Tomasello (1999), Haidt (2001, 2007), and Heyes (2012) defend different versions of the hypothesis that children and adults learn and internalise cultural norms through observation and imitation. This hypothesis can be applied to the transmission of honour codes, suggesting that observation and imitation of cultural practices throughout human development enable the internalisation of honour codes that foster HBV. Thus, imitation of honour-based behaviours may partake of the scaffolding of HBV.

A different type of cultural learning arises through counselling interactions with other relatives, friends and groups of elders. For example, in some rural areas of Pakistan, tribal councils named jirgas arbitrate honour conflicts and supervise decision making about issues of honour (Castetter 2002: p. 556-558). When individuals living in an honour-based culture find themselves in conflict or engaged in acts deemed dishonourable, they sometimes consult councils of peers for advice. This counselling may serve as an important means for culturally transmitting and enforcing cultural norms about the identification of honourable and shameful acts (Vandello and Cohen 2003: p. 1003). Counselling and cooperation in HBV are documented in numerous cases; and a number of reports consequently infer from this evidence that peer-pressure and peer-cooperation are distinctive of HBV (e.g., Belfrage et al. 2012; Gill 2014b: p. 5-7; Sen 2005).

In the migration context depicted in Fig. 1, extended family members who feel that their own honour is at stake may collectively pressure the immediate family to murder a woman in retaliation for the act of infringing their honour code. This kind of counselling and peer-pressure played an important role in the killing of Fadime and Banaz (Payton 2011). Honour-related counselling is also documented with respect to the economic management of matrimonial property and pecuniary transactions that sometimes motivate HBV (Bond 2014; Hussain 2006). Counselling about norms of honour can even occur during the perpetration of violence, which is sometimes described as pedagogical measure by perpetrators of HBV. For example, Akpinar (2003) reports the case of Ayla, a woman whose husband from an arranged marriage was beating her as an attempt to teach her "how to be a woman" according to his honour code (Akpinar 2003: p. 434).

\subsubsection{Institutions for the instruction and extenuation of perpetrators}

In addition to cultural transmission via teaching, historical scaffoldings for HBV comprise a variety of institutions that have played a role in establishing what is permissible and rectifiable in a honour-based culture (Cohen and Nisbett 1997; Strange 2014). Because these institutions can provide situational facilitation to the practice of $\mathrm{HBV}$, such institutions operate as historical scaffoldings of HBV. 
Educational institutions can be expected to play important roles in the transmission of honour codes that operate as scaffoldings of HBV. Unfortunately, information on the matter tends to be fragmented; Wikan notes that research is on the role of education in $\mathrm{HBV}$ is too limited and ambiguous (Wikan 2008: p. 71-72). Yet, some narratives provided in the literature are suggestive. For example, there is the story of an Egyptian man's memory from his school days in which he reports that his biology teacher, turning to a poster showing the female genital apparatus and pointing to the vaginal opening, stated: "Here is the site of the family honour!" (initially reported by Jehl 1999; discussed by Wikan 2008: p. 100). There is evidence that military schools played a role in the transmission of honour codes in Europe, including those in relation to duelling see Strange (2014).

Evidence regarding the legal scaffoldings of HBV is easier to access. A number of reports demonstrate that $\mathrm{HBV}$ is facilitated by laws that minimise legal punishment for perpetrators of $\mathrm{HBV}$ or make it dangerous for victims to report sexual violence (Bond 2014; Elakkary et al. 2014; Nesheiwat 2004; Okin 1999; Sen 2005; Warraich 2005; Warrick 2005; Welchman and Hossain 2005). An example of an judicial scaffolding of $\mathrm{HBV}$ is when members of the judiciary accepts honour-based provocation defences (see, e.g., Arnold 2001; Hussain 2006; Okin 1999; Warraich 2005). These defences holds that circumstances may cause a reasonable man to lose self-control after experiencing heightened emotions in response to an act that transgressed a honour code (Carline 2011). The defence can minimise the severity or length of the legal punishment imparted on perpetrators. Some countries have codified legal provisions that mitigate the offence or entirely exculpate murderers who purport to have killed for the sake of honour. The Jordanian Penal Code contains an exoneration of this kind codified as a statute in Article 340. Section (i) of this article states that "[h]e who catches his wife, or one of his female [relatives] committing adultery with another, and (...) kills, wounds, or injures one or both of them, is exempt from any penalty" (Arnold 2001). Wikan comments that "[e]mpathy for honor killing is built into the law" in the Jordanian legal system (Wikan 2008: p. 84).

Other institutional scaffoldings of HBV comprise ordinances utilised by perpetrators to grant victims and victim's families monetary compensation in return for forgiveness. In Pakistan, for example, Qisas and Diyat ordinances are a codification of the Islamic rule stating that a victim or her relatives and heirs can accept a form of monetary compensation from the perpetrator of $\mathrm{HBV}$ in return for forgiveness and an agreement to renounce legal complaint (Hussain 2006). The state must recognise forgiveness rights sought through these ordinances, which annuls formal legal punishment. Qisas and Diyat ordinances present another legal obstacle to effective redress of honour crimes (Appiah 2010; Hussain 2006).

\subsubsection{The omission of cultural learning in Baron-Cohen's (2011) model}

The examples provided above illustrate ways in which educational, legal and economic institutions can, as historical scaffoldings (see Fig. 1), contribute to perpetuating and legitimising HBV and perpetrators' fused identities. Thus, cultural learning of honour codes by a variety of social means - including parental teaching, peer counselling, cooperation and institutional encoding - can operate as a scaffolding for HBV. BaronCohen's (2011) model of empathy erosion does not analyse the roles played by cultural 
learning. This is a significant omission because cultural learning confers on perpetrators crucial resources to both undertake and justify HBV. Moreover, reference to cultural learning is relevant too for explaining the victims' decision.

\subsubsection{Victims' cultural learning of normative triggers of HBV}

Although I focused on perpetrators, examining the cultural learning of victims of HBV is also relevant to elucidating the emergence of conflict. In several cases following the script schematised in Fig. 1, the female victim of HBV is found to be have espoused norms and practices deviating from the honour code of her family, possibly acquired through group socialisation outside of her family home (Harris 1995: p. 463). A number of these victims of HBV seem to have been influenced by advocacy for human rights and institutions that operate as scaffoldings for the promotion of human rights, and specifically rights in relation to gender equality. These are in tension with honour codes that are valuing the asymmetric obedience to patriarchal authority (Okin 1989, 1999). Consider, for example, Fadime Sahindal's history of cultural learning. She embraced cultural norms of the Swedish liberal culture when she chose to have a boyfriend without requesting the consent of her family; and she had acted as an advocate for women's rights in front of the Parliament, just before being murdered. These actions expressed her critical, unfused personal identity. Wikan (2008, p. 100) summarises in broad terms the conflicting scaffoldings, as follows: "[t]he conflict is between, on one hand, principles of gender equality and ideals of liberty and human rights and, on the other, collective clan structures that celebrate patriarchal rule" (2008, p. 100).

\subsection{Scaffoldings for the erosion of empathy}

There is a third reason for preferring a psychohistorical approach to HBV over BaronCohen's individualistic model; it pertains to the analysis of emotions and empathy. In contrast to a view that locates the cause of HBV in a uniform lack of a empathy, a psychohistorical approach leads to the subtler view that situational factors can intensify, erode, or diversify empathic emotions implicated in HBV (Bloom 2016). This may be part of a more general process of contextual modulation of emotions in which fundamental characteristics and effects of emotions are altered as a result of changes in the decision maker's context of cultural and historical learning (Barrett 2017; Gibbard 1990; Matt and Stearns 2013). With respect to empathy in HBV, a hypothesis in line with this contextualist idea may be expressed as follows:

Scaffolded Erosion of Empathy. Culturally inherited honour codes and parochial attitudes can erode the perpetrators' empathy for victims of HBV and modulate other associated emotions.

To illustrate, erosion of a father's empathy for his daughter may result from his discoveries that she increasingly espouses outgroup norms that violate the code of honour of his community. To return to the murder of Fadime by her father, the evidence available about the case is consistent with Scaffolded Erosion of Empathy. Fadime's father appear to have experienced feelings of humiliation in response to Fadime's dissent. Such feelings count as contextually and historically modulated feelings because they were mediated by an internalisation of his community's honour code. As noted in Scaffolded Triggers, this internalisation was mediated by different types of cultural 
learning, which likely included parental and peer counselling, peer cooperation, and institutional facilitation. Under the pressure of the honour code's diktat and its communal costs, his feelings of shame and humiliation would then have been transformed into feelings of anger. Evidence of his anger were expressed during the trial of Fadime's murder, as Fadime's father repeatedly referred to her as "a whore". Her death according to him was the "final solution". And he exclaimed: "if you had a daughter like that, you would have wanted to shoot her too" (Wikan 2008p. 105, 111). In sum, his anger seemed to have resulted from the perceived humiliation caused by Fadime's decision to defy the code of honour of his community. Through his cultural learning, his emotions therefore emerged from an interaction with historical scaffoldings that are distinctive of HBV (see Section 4.2, and Fig. 1).

\section{Conclusive thoughts}

To recapitulate, my main aim was to offer the rudiments of a critique of individualism in the naturalistic theory of violence. I argued that, in the science of violence and evil, adopting a stern version of psychological individualism comes at a price. Using five objections, I noted that Baron-Cohen's individualistic theory of empathy erosion encounters serious difficulties when applied to a kind of communal violence like HBV. As an alternative to psychological individualism, I discussed a psychohistorical approach to HBV and the cultural malleability of empathy. The psychohistorical approach suggests that, in at least some cases of HBV, empathic and violent behaviour toward family members is scaffolded by systems of cultural learning coupled with complex contingent historical and economic circumstances.

As in other fields (Bullot 2014, 2015; Bullot and Reber 2013), psychohistorical hypotheses about violence can offer heuristics to mend the rift between individualistic and social explanations. Such hypotheses can, in turn, serve to generate intermediatescale models that combine psychological hypotheses with contextual evidence from either historiographical or ethnographical research. To illustrate this process, I provided the rudiments of a psychohistorical model HBV, which remains incomplete and mostly derived from evidence that remains patchy, contested and qualitative. To better understand how cultural learning and contingent contextual factors influence neural networks for empathy and emotions in $\mathrm{HBV}$, it would be beneficial to improve the connection between psychohistorical analysis and experimental research. More generally, it would be instructive to review and compare the variety of social, psychohistorical, and psychocultural models proposed for explaining violence in the its cultural and social diversity.

Another area of potential development for psychohistorical research concerns the philosophical gap between descriptive and normative accounts. Scientific explanations of violence are primarily descriptive (Baron-Cohen 2011; Fiske and Rai 2015). Other explanations subserve normative projects, which are aimed at changing attitudes and legal institutions (Bond 2014; Welchman and Hossain 2005) or even inviting moral revolutions (Appiah 2010). The normative projects are typically formulated in the language of highly contextualist methods of enquiry (Appiah 2010; Gill 2014a, 2014b; Kymlicka 2001). The psychohistorical approach offers an integrative framework for analysing the linkages between descriptive and the normative enquiries. From 
the standpoint of an individualistic model of empathy erosion, decision makers aiming at violence reduction ought to intervene on the minds of those who exhibit empathy erosion. But this strategy could lead to policies solely aimed at punishing individual perpetrators without changing the social scaffoldings of violence - see, above, Scaffolded Triggers. By contrast, the psychohistorical approach direct the decision maker's attention at the social scaffoldings and historical contexts that foster violence and atrocities. Consequently, the psychohistorical approach invites the decision maker seeking to reduce violence to change the social and legal structures that facilitate violence and silence victims.

Acknowledgments I would like to offer special thanks to Katherine Hardwick for her very substantive contributions as a research assistant at the beginning of this project. I am also very grateful to Shahd Al-Janabi, Lee Harrop, Robert A. Wilson, William C. Wimsatt and two anonymous reviewers for very helpful comments on earlier versions of this research. The early stage of this research was supported by a Discovery Award from the Australian Research Council (DECRA DP120102055).

Open Access This article is licensed under a Creative Commons Attribution 4.0 International License, which permits use, sharing, adaptation, distribution and reproduction in any medium or format, as long as you give appropriate credit to the original author(s) and the source, provide a link to the Creative Commons licence, and indicate if changes were made. The images or other third party material in this article are included in the article's Creative Commons licence, unless indicated otherwise in a credit line to the material. If material is not included in the article's Creative Commons licence and your intended use is not permitted by statutory regulation or exceeds the permitted use, you will need to obtain permission directly from the copyright holder. To view a copy of this licence, visit http://creativecommons.org/licenses/by/4.0/.

\section{References}

Abbas, T. (2011). Honour-related violence towards south Asian Muslim women in the UK: A crisis of masculinity and cultural relativism in the context of Islamophobia and the 'war on terror'. In M. M. Idriss \& T. Abbas (Eds.), Honour, violence, women and Islam (pp. 16-28). Abingdon, UK: Routledge.

Akpinar, A. (2003). The honour/shame complex revisited: Violence against women in the migration context. Women's Studies International Forum, 26(5), 425-442. https://doi.org/10.1016/j.wsif.2003.08.001.

Anderson, C. A., \& Bushman, B. J. (2002). Human aggression. Annual Review of Psychology, 53(1), $27-51$. https://doi.org/10.1146/annurev.psych.53.100901.135231.

Appiah, K. A. (2010). The honor code: How moral revolutions happen. New York, NY: W. W. Norton.

Arendt, H. (1963). Eichmann in Jerusalum: A report on the banality of evil. London, UK: The Penguin Group.

Arnold, K. C. (2001). Are the perpetrators of honor killings getting away with murder? Article 340 of the Jordanian penal code analyzed under the convention on the elimination of all forms of discrimination against women. American University International Law Review, 16(5), 1343-1410.

Atran, S. (2003). Genesis of suicide terrorism. Science, 299(5612), 1534-1539. https://doi.org/10.1126 /science.1078854.

Atran, S. (2014). Martyrdom's would-be myth buster. Behavioral and Brain Sciences, 37(04), 362-363. https://doi.org/10.1017/S0140525X13003555.

Atran, S., Sheikh, H., \& Gomez, A. (2014). For cause and comrade: Devoted actors and willingness to fight. Cliodynamics: The Journal of Quantitative History and Cultural Evolution, 5(1). Retrieved from http://www.escholarship.org/uc/item/6n09f7gr

Baker, N. V., Gregware, P. R., \& Cassidy, M. A. (1999). Family killing fields: Honor rationales in the murder of women. Violence Against Women, 5(2), 164-184. https://doi.org/10.1177/107780129952005.

Baron-Cohen, S. (2011). The science of evil: On empathy and the origins of cruelty. New York: Basic Books. Barrett, L. F. (2017). How emotions are made: The secret life of the brain. Boston: Houghton Mifflin Harcourt. Bechtel, W. (2008). Mental mechanisms: Philosophical perspectives on cognitive neuroscience. New York: Routledge. 
Belfrage, H., Strand, S., Ekman, L., \& Hasselborg, A.-K. (2012). Assessing risk of patriarchal violence with honour as a motive: Six years experience using the PATRIARCH checklist. International Journal of Police Science \& Management, 14(1), 20-29. https://doi.org/10.1350/ijps.2012.14.1.250.

Bettiga-Boukerbout, M. G. (2005). 'Crimes of honour' in the Italian penal code: An analysis of history and reform. In L. Welchman \& S. Hossain (Eds.), 'Honour': Crimes, paradigms and violence against women (pp. 230-244). London: Zed Books.

Bloom, P. (2016). Against empathy: The case for rational compassion. London: The Bodley Head.

Bloom, P. (2017a). Empathy and its discontents. Trends in Cognitive Sciences, 21(1), 24-31. https://doi. org/10.1016/j.tics.2016.11.004.

Bloom, P. (2017b). The root of all cruelty? Perpetrators of violence, we're told, dehumanize their victims. The truth is worse. The New Yorker. Retrieved from https:/www.newyorker.com/magazine/2017/11/27/theroot-of-all-cruelty/amp

Bond, J. (2014). Honour as familial value. In A. K. Gill, C. Strange, \& K. Roberts (Eds.), 'Honour' killing and violence: Theory, policy and practice (pp. 89-107). London: Palgrave Macmillan.

Browning, C. R. (1992/2001). Ordinary men: Reserve police Batallion 101 and the final solution in Poland. London: Penguin Books.

Bullot, N. J. (2014). Explaining person identification: An inquiry into the tracking of human agents. Topics in Cognitive Science, 6(4), 567-584. https://doi.org/10.1111/tops.12109.

Bullot, N. J. (2015). Agent tracking: a psycho-historical theory of the identification of living and social agents. Biology \& Philosophy, 30(3), 359-382.

Bullot, N. J., \& Reber, R. (2013). The artful mind meets art history: Toward a psycho-historical framework for the science of art appreciation. Behavioral and Brain Sciences, 36(02), 123-137. https://doi.org/10.1017 /S0140525X12000489.

Burge, T. (1986). Individualism and psychology. The Philosophical Review, 95(1), 3-45.

Caporael, L. R., Griesemer, J. R., \& Wimsatt, W. C. (Eds.). (2014). Developing scaffolds in evolution, culture, and cognition. Cambridge, MA: MIT Press.

Carline, A. (2011). Honour and shame in domestic homicide: A critical analysis of the provocation defence. In M. M. Idriss \& T. Abbas (Eds.), Honour, violence, women and Islam (pp. 80-95). Abingdon, UK: Routledge.

Castetter, M. D. (2002). Taking law into their own hands: Unofficial and illegal sanctions by the Pakistani tribal councils. Indiana International \& Comparative Law Review, 13, 543-578.

Chakravarti, U. (2005). From fathers to husbands: Of love, death and marriage in North India. In L. Welchman \& S. Hossain (Eds.), 'Honour': Crimes, paradigms and violence against women (pp. 308-331). London: Zed Books.

Choi, J.-K., \& Bowles, S. (2007). The coevolution of parochial altruism and war. Science, 318(5850), 636640. https://doi.org/10.1126/science.1144237.

Clark, A. J. (2003). Natural-born cyborgs: Minds, technologies, and the future of human intelligence. Oxford: Oxford University Press.

Clark, A. J., \& Chalmers, D. J. (1998). The extended mind. Analysis, 58(1), 7-19. https://doi.org/10.1093 /analys/58.1.7.

Cohen, D., \& Nisbett, R. E. (1997). Field experiments examining the culture of honor: The role of institutions perpetuating norms about violence. Personality and Social Psychology Bulletin, 23(11), 1188-1199. https://doi.org/10.1177/01461672972311006.

Coomaraswamy, R. (2005). Violence against women and 'crimes of honour'. In L. Welchman \& S. Hossain (Eds.), 'Honour': Crimes, paradigms and violence against women (pp. xi-xiv). London: Zed Books.

Cushman, F., Kumar, V., \& Railton, P. (2017). Moral learning: Psychological and philosophical perspectives. Cognition, 167(supplement C), 1-10. https://doi.org/10.1016/j.cognition.2017.06.008.

Downey, G., \& Lende, D. H. (2012). Neuroanthropology and the encultured brain. In D. H. Lende \& G. Downey (Eds.), The Encultured brain: An introduction to Neuroanthropology (pp. 23-65). Cambridge, MA: MIT Press.

Dwyer, P. G., \& Ryan, L. (Eds.). (2012). Theatres of violence: Massacre, mass killing and atrocity throughout history. New York: Berghahn Books.

Elakkary, S., Franke, B., Shokri, D., Hartwig, S., Tsokos, M., \& Püschel, K. (2014). Honor crimes: Review and proposed definition. Forensic Science, Medicine and Pathology, 10(1), 76-82. https://doi.org/10.1007 /s12024-013-9455-1.

Estany, A., \& Martínez, S. (2014). "Scaffolding" and "affordance" as integrative concepts in the cognitive sciences. Philosophical Psychology, 27(1), 98-111. https://doi.org/10.1080/09515089.2013.828569.

Fiske, A. P., \& Rai, T. S. (2015). Virtuous violence: Hurting and killing to create, sustain, end, and honor social relationships. Cambridge: Cambridge University Press. 
Fodor, J. A. (1980). Methodological solipsism considered as a research strategy in cognitive psychology. Behavioral and Brain Sciences, 3(01), 63-73. https://doi.org/10.1017/S0140525X00001771.

Gallagher, S. (2011a). Introduction: A diversity of selves. In The Oxford handbook of the self (pp. 1-29). Oxford: Oxford University Press.

Gallagher, S. (Ed.). (2011b). The Oxford handbook of the self. Oxford: Oxford University Press.

Gallagher, S., \& Hutto, D. D. (2008). Understanding others through primary interaction and narrative practice. In J. Zlatev, T. P. Racine, C. Sinha, \& E. Itkonen (Eds.), The shared mind: Perspectives on Intersubjectivity (pp. 17-38). Amsterdam: John Benjamins.

Galtung, J. (1990). Cultural violence. Journal of Peace Research, 27(3), 291-305. https://doi.org/10.1177 /0022343390027003005.

Gergen, K. J. (1973). Social psychology as history. Journal of Personality and Social Psychology, 26(2), 309320. https://doi.org/10.1037/h0034436.

Gibbard, A. (1990). Wise choices, apt feelings: A theory of normative judgment. Cambridge, MA: Harvard University Press.

Gill, A. K. (2009). Honor killings and the quest for justice in black and minority ethnic communities in the United Kingdom. Criminal Justice Policy Review, 20(4), 475-494. https://doi.org/10.1177 /0887403408329604.

Gill, A. K. (2014a). 'All they think about is honour': The murder of Shafilea Ahmed. In A. K. Gill, C. Strange, \& K. Roberts (Eds.), 'Honour' killing and violence: Theory, policy and practice (pp. 177-198). London: Palgrave Macmillan.

Gill, A. K. (2014b). Introduction: 'Honour' and 'honour'-based violence: Challenging common assumptions. In A. K. Gill, C. Strange, \& K. Roberts (Eds.), 'Honour' killing and violence: Theory, policy and practice (pp. 1-23). London: Palgrave Macmillan.

Gill, A. K., Strange, C., \& Roberts, K. (Eds.). (2014). 'Honour' killing and violence: Theory, policy and practice. London: Palgrave Macmillan.

Ginges, J., \& Atran, S. (2011). War as a moral imperative (not just practical politics by other means). Proceedings of the Royal Society B: Biological Sciences, 278(1720), 2930-2938. https://doi. org/10.1098/rspb.2010.2384.

Gold, L. H., \& Simon, R. I. (Eds.). (2016). Gun Violence and Mental Illness. Arlington, VA: American Psychiatric Association.

Haidt, J. (2001). The emotional dog and its rational tail: A social intuitionist approach to moral judgment. Psychological Review, 108(4), 814-834. https://doi.org/10.1037//0033-295x.108.4.814.

Haidt, J. (2007). The new synthesis in moral psychology. Science, 316(5827), 998-1002. https://doi. org/10.1126/science.1137651.

Hall, J. A., \& Bernieri, F. J. (Eds.). (2001). Interpersonal sensitivity: Theory and measurement. Mahwah, NJ: Lawrence Erlbaum.

Harris, J. R. (1995). Where is the child's environment? A group socialization theory of development. Psychological Review, 102(3), 458-489. https://doi.org/10.1037/0033-295X.102.3.458.

Heider, F. (1958). The psychology of interpersonal relations. New York: Wiley.

Henrich, J. (2016). The secret of our success: How culture is driving human evolution, domesticating our species, and making us smarter. Princeton, NJ: Princeton University Press.

Heyes, C. M. (2012). Grist and mills: On the cultural origins of cultural learning. Philosophical Transactions of the Royal Society B: Biological Sciences, 367(1599), 2181-2191. https://doi.org/10.1098 /rstb.2012.0120.

Heyes, C. M., \& Frith, C. D. (2014). The cultural evolution of mind reading. Science, 344(6190). https://doi. org/10.1126/science.1243091.

Hinton, A. L. (2004). Why did they kill? Cambodia in the shadow of genocide. Berkeley: University of California Press.

Honderich, T. (2002). How Free Are You?: The Determinism Problem: Oxford University press.

Honneth, A. (1996). The struggle for recognition: The moral grammar of social conflicts (J. Anderson, Trans. Cambridge, MA: MIT Press.

Hoyek, D., Sidawi, R. R., \& Mrad, A. A. (2005). Murders of women in Lebanon: 'Crimes of honour' between reality and the law. In L. Welchman \& S. Hossain (Eds.), 'Honour': Crimes, paradigms and violence against women (pp. 111-136). London: Zed Books.

Hussain, M. (2006). Take my riches, give me justice: A contextual analysis of Pakistan's honor crimes legislation. Harvard Journal of Law \& Gender, 29, 223-246.

Husseini, R. (2011). A comparative study of the reform work conducted in Asia and Europe to combat violence and 'so-called' honour murders. In M. M. Idriss \& T. Abbas (Eds.), Honour, violence, women and Islam (pp. 154-167). Abingdon, UK: Routledge. 
Idriss, M. M. (2011). Honour, violence, women and Islam - An introduction. In M. M. Idriss \& T. Abbas (Eds.), Honour, violence, women and Islam (pp. 1-15). Abingdon, UK: Routledge.

Idriss, M. M., \& Abbas, T. (Eds.). (2011). Honour, violence, women and Islam. Abingdon, UK: Routledge. Jehl, D. (1999). Arab honor's price: A woman's blood. New York Times, p. 1.

Jones, E. E., Kanouse, D. E., Kelley, H. H., Nisbett, R. E., Valins, S., \& Weiner, B. (Eds.). (1971). Attribution: Perceiving the causes of behavior. Morristown, NJ: General Learning Press.

Kuhn, T. S. (1962/1996). The structure of scientific revolutions (Third ed.). Chicago: The University of Chicago Press.

Kurkiala, M. (2003). Interpreting honour killings: The story of Fadime Sahindal (1975-2002) in the Swedish press. Anthropology Today, 19(1), 6-7. https://doi.org/10.2307/3695150.

Kyle, C., McEwen, S., \& DeFelice, J. (2012). American Sniper: The Autobiography of the Most Lethal Sniper in U.S. Military History. New York, NY: Harper.

Kymlicka, W. (2001). Politics in the vernacular: Nationalism, multiculturalism and citizenship. Oxford: Oxford University Press.

Lakoff, G. (2009/2008). The political mind: A cognitive Scientist's guide to your brain and its politics. New York: Penguin Books.

Lankford, A. (2014). Précis of the myth of martyrdom: What really drives suicide bombers, rampage shooters, and other self-destructive killers. Behavioral and Brain Sciences, 37(04), 351-362. Doi:Doi:10.1017/ S0140525X13001581.

Lende, D. H., \& Downey, G. (Eds.). (2012). The Encultured brain: An introduction to Neuroanthropology. Cambridge, MA: MIT Press.

Lifton, R. J. (1986). The Nazi doctors: Medical killing and the psychology of genocide. USA: Basic Books.

Lifton, R. J., \& Olson, E. (Eds.). (1974). Explorations in psychohistory: The Wellfleet papers. New York: Simon and Schuster.

List, C., \& Pettit, P. (2011). Group agency: The possibility, design, and status of corporate agents. Oxford: Oxford University Press.

Lukes, S. (1968). Methodological individualism reconsidered. The British Journal of Sociology, 19(2), 119129. https://doi.org/10.2307/588689.

Lukes, S. (2005). Power: A Radical View (Second Edition). Basingstoke, UK: Palgrave MacMillan.

Marr, D. (1982). Vision. San Francisco: W. H. Freeman.

Matt, S. J., \& Stearns, P. N. (Eds.). (2013). Doing emotions history. Urbana, IL: University of Illinois Press.

McGinty, E. E., Webster, D. W., \& Barry, C. L. (2013). Effects of news media messages about mass shootings on attitudes toward persons with serious mental illness and public support for gun control policies. American Journal of Psychiatry, 170(5), 494-501. https://doi.org/10.1176/appi.ajp.2013.13010014.

Menary, R. (2013). Cognitive integration, enculturated cognition and the socially extended mind. Cognitive Systems Research, 25, 26-34.

Metzl, J. M., \& MacLeish, K. T. (2015). Mental illness, mass shootings, and the politics of American firearms. American Journal of Public Health, 105(2), 240-249. https://doi.org/10.2105/ajph.2014.302242.

Milgram, S. (1974/2004). Obedience to authority: An experimental view. New York: Perennial Classics.

Mitchell, S. D. (2009). Unsimple truths: Science, complexity, and policy. Chicago, IL: University of Chicago Press.

Moisi, D. (2010). The Geopolitics of Emotion: How Cultures of Fear, Humiliation, and Hope Are Reshaping the World: Anchor.

Morton, A. (2004). On Evil. New York: Routledge.

Nesheiwat, F. K. (2004). Honor crimes in Jordan: Their treatment under Islamic and Jordanian criminal laws. Penn State International Law Review, 23(2), 251-282.

O'Neill, S., \& Smith, N. H. (Eds.). (2012). Recognition theory as social research: Investigating the dynamics of social conflict. Houndmills, Basingstoke: Palgrave Macmillan.

Okin, S. M. (1989). Justice, gender, and the family. New York: Basic Books.

Okin, S. M. (1999). Is multiculturalism bad for women? In S. M. Okin, J. Cohen, M. Howard, \& M. C. Nussbaum (Eds.), Is multiculturalism bad for women? (pp. 9-17). Princeton, NJ: Princeton University Press.

Oprisko, R. L. (2012). Honor: A phenomenology. New York: Routledge.

Payton, J. (2011). Collective crimes, collective victims: A case study of the murder of Banaz Mahmod. In M. M. Idriss \& T. Abbas (Eds.), Honour, violence, women and Islam (pp. 77-79). Abingdon, UK: Routledge.

Pimentel, S., Pandjiarjian, V., \& Belloque, J. (2005). The 'legitimate defence of honour', or murder with impunity? A critical study of legislation and case law in Latin America. In L. Welchman \& S. Hossain (Eds.), 'Honour': Crimes, paradigms and violence against women (pp. 245-262). London: Zed Books. 
Ramstead, M. J. D., Veissière, S. P. L., \& Kirmayer, L. J. (2016). Cultural affordances: Scaffolding local worlds through shared intentionality and regimes of attention. Frontiers in Psychology, 7(1090). https://doi.org/10.3389/fpsyg.2016.01090.

Rogoff, B. (2003). The cultural nature of human development. Oxford: Oxford University Press.

Ryan, L. (2010). Settler massacres on the port Phillip frontier, 1836-1851. Journal of Australian Studies, 34(3), 257-273. https://doi.org/10.1080/14443058.2010.498091.

Sen, P. (2005). 'Crimes of honour', value and meaning. In L. Welchman \& S. Hossain (Eds.), 'Honour': Crimes, paradigms and violence against women (pp. 42-63). London: Zed Books.

Siddiqi, D. M. (2005). Of consent and contradiction: Forced marriages in Bangladesh. In L. Welchman \& S. Hossain (Eds.), 'Honour': Crimes, paradigms and violence against women (pp. 282-307). London: Zed Books.

Siddiqui, H. (2005). 'There is no "honour" in domestic violence, only shame!' Women's struggles against 'honour' crimes in the UK. In L. Welchman \& S. Hossain (Eds.), 'Honour': Crimes, paradigms and violence against women (pp. 263-281). London: Zed Books.

Smith, D. L. (2011). Less Than Human: Why We Demean, Enslave, and Exterminate Others: St. Martin's Press.

Smith, D. N. (1998). The psychocultural roots of genocide: Legitimacy and crisis in Rwanda. American Psychologist, 53(7), 743-753. https://doi.org/10.1037/0003-066X.53.7.743.

Staub, E. (2000). Genocide and mass killing: Origins, prevention, healing and reconciliation. Political Psychology, 21(2), 367-382. https://doi.org/10.1111/0162-895X.00193.

Staub, E. (2003). The psychology of good and evil: Why children, adults, and groups help and harm others. Cambridge: Cambridge University Press.

Sterelny, K. (2010). Minds: Extended or scaffolded? Phenomenology and the Cognitive Sciences, 9(4), 465481. https://doi.org/10.1007/s11097-010-9174-y.

Strange, C. (2014). Adjusting the lens of honour-based violence: Perspective from euro-American history. In A. K. Gill, C. Strange, \& K. Roberts (Eds.), 'Honour' killing and violence: Theory, policy and practice (pp. 46-68). London: Palgrave Macmillan.

Sutton, J. (2010). Exograms and interdisciplinarity: History, the extended mind, and the civilizing process. In R. Menary (Ed.), The extended mind (pp. 189-225). Cambridge, MA: MIT Press.

Swann Jr., W. B., Buhrmester, M. D., Gómez, A., Jetten, J., Bastian, B., Vázquez, A., et al. (2014). What makes a group worth dying for? Identity fusion fosters perception of familial ties, promoting self-sacrifice. Journal of Personality and Social Psychology, 106(6), 912-926. https://doi.org/10.1037/a0036089.

Swann Jr., W. B., Gómez, Á., Dovidio, J. F., Hart, S., \& Jetten, J. (2010). Dying and killing for one's group: Identity fusion moderates responses to intergroup versions of the trolley problem. Psychological Science, 21(8), 1176-1183. https://doi.org/10.1177/0956797610376656.

Swann Jr., W. B., Gómez, Á., Seyle, D. C., Morales, J. F., \& Huici, C. (2009). Identity fusion: The interplay of personal and social identities in extreme group behavior. Journal of Personality and Social Psychology, 96(5), 995-1011. https://doi.org/10.1037/a0013668.

Taylor, C. (1994). The politics of recognition. In A. Gutmann (Ed.), Multiculturalism (pp. 25-74). Princeton, NJ: Princeton University Press.

Thagard, P. (2019). Natural philosophy: From social brains to knowledge, reality, morality, and beauty. New York, NY: Oxford University Press.

Thapar-Björkert, S. (2011). Conversations across borders: Men and honour-related violence in the UK and Sweden. In M. M. Idriss \& T. Abbas (Eds.), Honour, violence, women and Islam (pp. 182-198). Abingdon, UK: Routledge.

Tollefsen, D. P. (2015). Groups as agents. Cambridge, UK: Polity.

Tomasello, M. (1999). The cultural origins of human cognition. Cambridge, MA: Harvard University Press.

Towers, S., Gomez-Lievano, A., Khan, M., Mubayi, A., \& Castillo-Chavez, C. (2015). Contagion in mass killings and school shootings. PLoS One, 10(7), e0117259. https://doi.org/10.1371/journal.pone.0117259.

Vandello, J. A., \& Cohen, D. (2003). Male honor and female fidelity: Implicit cultural scripts that perpetuate domestic violence. Journal of Personality and Social Psychology, 84(5), 997-1010. https://oi. org/10.1037/0022-3514.84.5.997.

Vygotsky, L. S. (1987). Thinking and speech. In R. W. Rieber \& A. S. Carton (Eds.), The collected works of L. S. Vygotsky, volume 1: Problems of general psychology (pp. 38-285). New York, NY: Plenum Press.

Waller, J. (2002). Becoming Evil: How Ordinary People Commit Genocide and Mass Killing: Oxford University press.

Warraich, S. A. (2005). 'Honour killings' and the law in Pakistan. In L. Welchman \& S. Hossain (Eds.), 'Honour': Crimes, paradigms and violence against women (pp. 78-110). London: Zed Books.

Warrick, C. (2005). The vanishing victim: Criminal law and gender in Jordan. Law \& Society Review, 39(2), 315-348. https://doi.org/10.1111/j.0023-9216.2005.00084.x. 
Watkins, J. W. N. (1957). Historical explanation in the social sciences. The British Journal for the Philosophy of Science, 8(30), 104-117. Retrieved from http://www.jstor.org/stable/685790

Welchman, L., \& Hossain, S. (Eds.). (2005). 'Honour': Crimes, paradigms and violence against women. London: Zed Books.

Wikan, U. (2008). In honor of Fadime: Murder and shame (A. Paterson, Trans. Chicago: University of Chicago Press.

Wilson, R. A. (1992). Individualism, causal powers, and explanation. Philosophical Studies, 68, $103-139$. https://doi.org/10.1007/BF00354473.

Wilson, R. A. (2004). Boundaries of the mind, the individual in the fragile sciences: Cognition. Cambridge: Cambridge University Press.

Wimsatt, W. C. (2014). Entrenchment and scaffolding: An architecture for a theory of cultural change. In L. R. Caporael, J. R. Griesemer, \& W. C. Wimsatt (Eds.), Developing scaffolds in evolution, culture, and cognition (pp. 77-105). Cambridge, MA: MIT Press.

Wold, L. (2019). Inside an honor killing: A father and a daughter tell their story (O. Lasky, Trans. Vancouver, BC: Greystone Books.

Wood, D., Bruner, J. S., \& Ross, G. (1976). The role of tutoring in problem solving. Journal of Child Psychology and Psychiatry, 17(2), 89-100. https://doi.org/10.1111/j.1469-7610.1976.tb00381.x.

Zimbardo, P. G. (2007). The Lucifer effect: Understanding how good people turn evil. New York: Random House.

Publisher's note Springer Nature remains neutral with regard to jurisdictional claims in published maps and institutional affiliations. 